\title{
Conservative Strategies for Dismantling Independent Oversight and Advocacy Joe Convict
}

Tf any government wants the power to control or destroy a charity that does not or will not conform to state or partisan interests, that government must first subvert the autonomy of that charity. This can be accomplished very effectively by getting that charity fatally addicted to government funding. This in turn makes them vulnerable to the whims of state ideologies and systematic sabotage. Further, it disconnects them from the protection of public opinion by alienating them from their support base that would normally have been informed about their cause through the process of fundraising.

Sadly, this is no obscure conspiracy theory. This is exactly what has happened and is happening to prisoner advocacy groups, charities, and many other non-governmental organizations (NGOs) throughout Canada. The government is utilizing a very ancient warfare strategy against its own citizens, in order to silence any opposition to their increasingly totalitarian agenda, which is not restricted to the law-breaker. You may know this strategy as the myth of the Trojan Horse. The once seemingly altruistic motives behind the government's funding of non-profit prisoner advocacy groups have been tragically revealed.

For example, let us look at the recent demise of Life Line, a lifers' support group that gave up more and more control to the illusion of easy government funding. This then allowed for the methodical infiltration of government minders and oversight, the end result of which was that their funding was arbitrarily pulled. The group no longer exists (Griffin, 2012).

Below are a few more examples of conservative funding cuts that are negatively targeting and defunding all NGOs and charity groups, those who engage in any kind of social justice advocacy that might affect prisoners' rights, either directly or indirectly. The John Howard Society (JHS), HIV/ AIDS groups (Paperny, 2012), street-level outreach and health clinics, up to 80 per cent of funding to all aboriginal advocacy groups, all federally contracted ambulatory psychiatric nurses, contract religious leaders (i.e. the Salvation Army, M1M2, Community Chaplaincies across Canada), and any other poverty groups whose main clientele consists of the poor, street people, prostitutes, drug addicts, mentally ill, or prisoners and ex-prisoners (MSCM Montreal, 2012). This is a longstanding strategy to destroy hope because a prisoner who, out of sheer despair, has no faith, has no hope, and is less likely to resist the abuses by state and prison officials. 
I am unsure how bad the JHS offices across the country have been hit as I have been unable to reach them by phone for some time, but they are surely next on the chopping block. JHS was once known as Canada's oldest prisoners' rights advocacy group. Advocacy on the part of local JHS offices is already next to absent in my communities, leaving the national JHS to do much of this work. As funding from other streams has dried up, they have become more dependent on government support. They have very publicly declared themselves to be a partner of the Correctional Service of Canada (CSC) and have been largely reduced to an ex-prisoner support group almost solely funded by the state (United Way, 2008).

Each program JHS receives funding for must first conform to a strict standard of zero advocacy for those still incarcerated if that advocacy is critical of the state, prison policy, or prisoner treatment. Even if a prisoner were to complain to JHS about being tortured and needing help, the organization is mandated to remain silent or risk having all future funding cut (I speak from personal experience). This once proudly independent advocate for real prisoner protection, oversight, and human rights has become just another generic arm of government-styled welfare. This is great for those being released but does nothing to improve the everdeteriorating conditions within prisons themselves. From my perspective, the new position of the JHS only perpetuates the state's totalitarian agenda of creating a secretive and barbaric prison system, free from accountability.

There is an entrenched culture of arrogance and impunity within prisons. They are more unjust and corrupt than any other arm of the criminal justice system. For the record, the Office of Correctional Investigator (OCI) is not now, nor has ever been, an ombudsman. They are under the same act as CSC, which is the Correctional and Conditional Release Act (CCRA), more specifically, CCRA sections 158-196 (3)(b)(ii).

Furthermore, all investigation reports and comments presented to Parliament or the public must first be censored, vetted, and preapproved by the Public Safety Minister, who is also in charge of CSC. The OCI by law cannot act without ministerial consent or as an ombudsman for the federal prisoner, because this would assume their official role to be an advocate for the protection of the rights of the public as well as the prisoner against CSC and the state. This, however, is definitely not the case. Additionally, to their discredit, in a clear conflict of interest, OCI routinely hires individuals from all over the criminal justice sector, including ex-corrections staff. 
Now, by a single amendment to the CCRA, via the so-called Safe Streets and Communities Act, the Conservatives' despotic agenda of dismantling all constitutional, legal, and human rights for prisoners has been realized. In brief, the amendment states that CSC now has the power to circumvent all Canadian law or infringe upon any constitutional right, when creating or implementing prison policy in federal prisons as long as they first declare it to be in the best interest of "public safety". This, of course, makes the enshrined right to the least restrictive measures within federal prisons, which are guaranteed under the Constitution, null and void.

What is even more terrifying is their further unconstitutional amendments that give CSC the power to stop prisoners from communicating with anyone outside the prison for any reason. This includes lawyers, the courts, lawmakers, and the media, not to mention family. This can create a complete media and communications blackout for information coming into the prisons (i.e. radio and television), as well as periodicals and literature (Ormsby, 2012). Such tactics amount to a complete silencing of free speech and freedom of the press, and a total abrogation of protection under the law. The Conservative Party, our government, has once again made it completely legal to hold federal prisoners totally incommunicado, a clear contravention of Canadian and international law.

They have even gone so far as to support new private member's legislation (Bill C-293) that grants CSC the power to declare a prisoner a "vexatious griever". When invoked, CSC removes the prisoner's ability to complain about anything without the prisoner first being given leave by the courts to do so. What this literally means for the prisoner's ability to access justice is the total loss of all right to seek internal resolutions for abuse, no matter how legitimate the complaint, even a complaint about torture. Now weigh this fact against this country's already overburdened judicial system and the lack of funding for the many court challenges already desired by federal prisoners. Finally, the last nail in the coffin of justice, or prisoners' constitutional rights, is the pre-existing two-tier justice system, under which only the affluent of our society can enjoy full access to the courts or protection under the law. And there you have it, the creation of a diabolically evil, draconian prison system, void of accountability, human decency, morality, or the law.

From a historical perspective, we must remember that every atrocity in which Hitler ever engaged was completely legal according to German law. 
I ask all who hear or read these words: Will you sit idly by while the state uses terror tactics to justify the outright persecution and dehumanization of the "lawbreaker/prisoner"? Will you not stand up to save this country's democracy from a government that would utilize warfare and propaganda strategies to discredit or destroy even their law-abiding critics, regardless of whether they are charities, NGOs, or the average citizen? Do not let the assumption of "it can never happen in Canada" blind you to the absolute fact that these things are happening and will continue to get worse unless you proactively step up.

\section{REFERENCES}

Griffin, Ed (2012, May 21) "Cuts to CSC budget: What will they mean?", Prison Uncensored - The Truth Behind the Bars. Retrieved from $<\mathrm{http}: / /$ prisonuncensored. wordpress.com/2012/05/21/cuts-to-csc-budget-what-will-they-mean/>.

MSCM Montreal (2012) "Say no to chaplaincy cuts in our prisons" - October 22. Retrieved from <http://goarticles.com/article/Say-No-to-Chaplaincy-Cuts-in-OurPrisons/7074776/>.

Ormsby, Mary (2012) "Kingston Penitentiary won't deliver Toronto Star letters to inmates" - October 2. Retrieved from <http://www.thestar.com/news/canada/2012/10/02/ kingston_penitentiary_wont_deliver_toronto_star_letters_to_inmates.html $>$.

Paperny, Anne-Marie (2012) "Fearing advocacy, Ottawa rejects HIV/AIDS funding proposals", Globe and Mail - August 6.

United Way of Sarnia-Lambton (2008) "United Way announces funding cut to John Howard Society and announces new Venture Grant". Retrieved from $<\mathrm{http}: / / \mathrm{www}$. theunitedway.on.ca/2012-09-06-14-14-25/81-united-way-announces-funding-cutto-john-howard-society-and-announces-new-venture-grant.html>.

\section{ABOUT THE AUTHOR}

Joe Convict is a Canadian who has served more than twenty-five years in prison and who prefers to write using a pseudonym. 